Tér és Társadalom 6. 1992:1-2: 89-99

\title{
KITEKINTÖ
}

\section{A TERÜLETRENDEZÉS DILEMMÁI A DEMOKRATIKUS PIACGAZDASÁGOKBAN}

\section{(Dilemmas of land use planning in a democracy with a market economy)}

\author{
KENNETH K. BAAR
}

\section{Bevezetés}

A városi társadalmakban a területfelhasználás szabályozása központi szerepet játszik. Meghatározó a városi (szuburbánus) élet minôségének és módjának, az egyes társadalmi rétegek integrálódásának vagy szegregálódásának, munkához és társadalmi szolgáltatásokhoz jutásuk esélyeinek szempontjából, és a infrastruktura igények és a fogyasztási minták kialakulásában is jelentốs szerepet játszik.

A területfelhasználás szabályozása éppúgy serkenti a régi városközpontok helyreállítását, kellemes lakókörnyezet és sétálóutcák kialakítását, mint a korunk újabb városaira jellemzô, siváran terpeszkedố, személytelen megastrukturák létrehozását. Másszóval a területfelhasználâs szabályozása áll a többlakásos házakból illetve a kertvárosi villákból álló városok közötti különbség hátterében.

A területfejlesztés és a területfelhasználás szabályozásának magyarországi rendszere alapvetớ átalakuláson megy keresztül. A városrendezési jog- és hatáskörök korábban formálisan kötởdtek a helyi hatóságokhoz, a várostervezés direktíváit azonban fốként a monopolhelyzetú állami tervezốvállalatok szakértôi szabták meg. Az elképzeléseket egyfelôl az egypártrendszer kỏzponti és helyi politikai hatóságai, másfelốl az informális politikai erốk alakították. Az építôipar hasonlóképp monopolhelyzetũ állami vállalatok kezében volt, a magánerôs fejlesztés csalâdiházas és társasházas lakóterületekre korlátozódott.

A várostervezés ma a többpárti irányítású közigazgatás keretein belül decenetralizáltan és demokratizáltan folyik. A fejlesztés feladataira egyre inkább a magánszektor vállalkozik. Míg korábban az ,állam” egyszerre volt hatóság és városfejlesztô, most ezek különbözố szereplók - hasonló, vagy ellentétes érdekekkel. A területfejlesztésben az állam szerepe lényegében a feladat végrehajtásáról eltolódott a magánkezdeményezésû́, piac-orientált városfejlesztés szaballyozása felé.

A Környezetvédelmi és Területfejlesztési Minisztériumban ezidôtájt zajlik az Építési és területfelhasználási törvény revíziója, a helyi önkormányzatok pedig saját rendezési terveiket vizsgálják felül. ${ }^{1}$

$\mathrm{Az}$ átmeneti idôszak jobb megértése végett meg kell jegyeznünk, hogy a területfelhasználás szabályozásának fontosságát némileg csökkentette az a tény, hogy a fejlesztések volumene a 
rendszerváltás kezdete óta alacsony. ${ }^{2}$ A kormány feladta korábbi építtetôi szerepét, kedvezményes építési kölcsönöket sem biztosít a továbbiakban, ugyanakkor a magas infláció ${ }^{3}$ az ingatlanpiaci magánkölcsönökkel való finanszírozást is lehetetlenné tette.

A demokrácia követelményei azonban fontossá tették az azonnali reformokat. Egyes speciális esetekben a szabályozást azért kell megváltoztatni, hogy olyan területfelhasználást is engedélyezni lehessen, amelyet a jelenlegi szabályozás nem tesz lehetôvé.

A helyi infrastruktura és a fejlesztések gazdasági felelôsségének egyidejư átadásával a várostervezés valódi döntési jogköre került az önkormányzatok kezébe. Magyarország városi morfológiája alapvetôen megváltozhat, minthogy az állami hiteltámogatás és lakásépítés megszúnésével a magánerôs családiház építés marad az egyetlen járható út a lakásépítés területén.

E cikk célja az, hogy bemutassa azokat a tipikus kérdéseket, dilemmákat, amelyek a piacgazdaságra és a területfelhasználás kontrolljának decentralizálására épülỏ poszt-indusztriális, demokratikus társadalmakban jelentkeznek a területfelhasználási tervezéssel kapcsolatosan.

A szerzô véleményét az Egyesült Államokban szerzett tapasztalataira, a magyar várostervezôkkel folytatott megbeszélésekre és a magyar jogszabályrendszer áttekintésére alapozza. Bár az Egyesült Államok városainak képe gyökeresen különbözik a magyar városokétól, a szerzố úgy gondolja, hogy az amerikai várostervezéshez kötôdő dilemmák nemcsak érdekesek lehetnek, de valóban fel is vetik azokat a kérdéseket, amelyek minden nyugati demokratikus kulturában felmerülnek, különösen ott, ahol a várostervezés jogköre erôsen decentralizált.

Bár az alábbi elemzés kritikus a piacgazdaságon alapulú demokratikus társadalmak tervezési folyamatával szemben, a szerző nem állítja, hogy valamilyen más rendszer jobb lenne. Inkább az lenne a célja, hogy olyan áttekintést adjon, amely Magyarországon is segítheti a nagyobb figyelem, a megértés és tolerancia kialakulását a felbukkanó nehézségekkel szemben.

\section{A területfelhasználás tervezésének fejlódése az Egyesült Államokban}

Az Egyesült Államok területfelhasználási tervezésében érzékelhetô mai dilemmák megértéséhez elengedhetetlen a fejlôdés hátterének rövid áttekintése.

\section{A területfelhasználás szabályozásának megjelenése és a „,családiházas álom”}

Bár a ,tervezés" a kommunizmus gyakorlatának tû́nhet, tudnunk kell, hogy a településtervezés és a területfelhasználás szabályozása piacgazdaságokban is alapvetô fontosságú a városok sikeres múködéséhez. A XX. sz. elsổ negyedében az amerikai vállalkozók, ingatlanügynökök, bankárok központi szerepet vállaltak a területfelhasználási szabályozása bevezetése érdekében.

Ebben az idốszakban az Egyesült Államok Legfelsốbb Bírósága azt az álláspontot képviselte, hogy a szabad verseny laisser faire (pl. a szerzôdések szabadsága) alkotmányos jog. Ezért két-

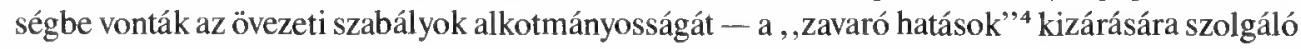
szabályozás kivételével.

Építési övezetek (zoning) hiányában a magánfejlesztôk és a háztulajdonosok csoportjai a kormányzat részvétele nélkül létrehozott magánszerzôdések (, ,korlátozó megállapodások”"5) révén igyekeztek biztosítani, hogy fejlesztési projektjeik megôrizzék eredeti jellegüket, s hogy végül 
Kenneth K. Baar : A területrendezés dilemmái a demokratikus piacgazdaságokban

(Pilemmas of land use planning in a democracy with a market economy)

Tér és Társadalom 6. évf. 1992/1-2. 89-99. $p$.

elérjék a funkcionális zónák kialakulását. Ezek a megállapodások azonban hosszabb távon alkalmatlannak bizonyultak. Miközben adott idôppontban biztosították, hogy a területen csak meghatározott használati funkciók jelenjenek meg, hosszabb távon rugalmatlannak bizonyultak, mert nem tudták követni a változó körülményeket, hiszen csak teljes egyetértés alapján lehetett a szabályokat megváltoztatni.

A különféle típusú - pl. kereskedelmi, ipari, lakóterületi - ingatlanhasználatot elkülönítő övezeti rendszer bevezetését többféle érdek indokolta. A tervezốk közt uralkodó nézet szerint a kủlönféle funkciók teljes szétválasztása az egészséges társadalom létrehozása érdekében elkerülhetetlen. A lakásépítés reformerei és más progresszív erổk ezen túlmenôen úgy gondolták, hogy a kívánatos társadalom érdekében a lakosságot feltétlenül családi házakban kell elhelyezni.

Egy vezetổ amerikai lakásügyi reformer kifejtette, hogy

„,Kétségkívül meglévô, és több szempontból is kimutatható elổnyei ellenére a többlakásos lakóház egyértelmưen a város fejlổdésének kárára van. Gátolja a megfelelổ szociális körülmények kialakulását és a valódi polgári tudat kifejlốdését. A város, ahol a többlakásos lakóház elterjedt, nem lehet az igazi otthonok városa."

\section{A lakásügyek egyik professzorának megjegyzései is a kor sztereotípiáit tükrözik:}

„,... A legdrágább apartment, és a legolcsóbb bérlemény egyaránt kedvezổtlen környezet még a gyermektelen családok számára is, mert a betegségek könnyedén terjednek egyik lakásból a másikba a közös hall vagy a vándorló bogarak útján. ${ }^{7}$

Ahol az emberek többlakásos házakban élnek, a városi népesség sürüsége olyan magas, hogy a környezô utcákon mindig nagy lesz a forgalom. A por és a lárma miatt ez az élet forma felettébb kellemetlen. A szomszéd lakásból áthallatszó zajok lehetetlenné teszik a pihenést és a nyugalmat. Bár az egyén fejlôdése szempontjából rendkívủl fontos lenne, az egyedüllét vagy a valódi magánélet kialakítása ilyen körülmények között nehezen érhetô el. A gyerekes családok számára a nagy lakóház még kevésbé kívánatos. Az édesanya nem tudja úgy megválasztani gyerekei játszótársait, hogy az ne kerüljön kapcsolatba a házban lakó, ,,rossz" gyerekekkel vagy felnốttekkel, a lakáson kívül nem tudja szemmel tartani gyerekei játékát. Egészében véve a bérházak atmoszférája egészségtelen, vézna, szociálisan kiegyensúlyozatlan felnốtteket nevel. ${ }^{8}$

A lakásügyi reformok, az építési vállalkozók, a hiteleket nyújtó bankárok egyaránt úgy vélték, hogy a családiházas építkezés tömeges elterjedéséhez elengedhetetlen, hogy a terület a bérházak vagy más zavaró funkciók , ,inváziójától" védett legyen. ${ }^{9}$ Az Egyesült Államok Kereskedelmi Minisztériuma csatlakozott a családiházas övezeti szabályozás kialakításáért indított mozgalomhoz.

Az 1920-as évekre az alkotmányossággal kapcsolatos bizonytalanságok ellenére az övezeti szabályozás széles körben elterjedt. Végül 1926-ban a Legfelsốbb Bíróság a szakemberek indokai alapján olyan határozatot hozott, hogy az övezeti szabályozás nem alkotmányellenes. ${ }^{10} \mathrm{~A}$ Bíróság döntése különösen annak fényében figyelemre méltó, hogy olyan idôszakban született, amikor a ,,szerzôdések szabadságára" hivatkozva olyan törvényeket is indokolatlannak tartottak és érvénytelenítettek, mint pl. a minimális munkabérek vagy a maximális munkaidô szabályozása. ${ }^{11}$ Ugyanaz a bíróság, amelyik úgy vélte, hogy a munkaviszonyokat rendezổ szabálynak nincs ésszerũ alapja, megmagyarázta, hogy miért tekinthetổ közérdekưnek a családiházas övezetek kialakítása.

, A családi házas területek kialakulását erốsen veszélyezteti a többlakásos házak megjelenése... Az ilyen területeken a bérház egyszerủen élốsdi, amely kihasználja a környék lakójellegébôl, szellỗs és vonzó megjelenésébổl származó előnyöket. Az elsố bérházat követi a többi, magasságukkal és tömegükkel megakadályozzák a szabad légáramlást, kisajátítják a kisebb házak elổl a napsütést. Elkerülhetetlenül velük érkezik a megnövekedett forgalomhoz és városi élethez 
kötốdỡ zaj..., s végül teljesen eltũnnek a környék korábbi lakóterületi vonásai és a családi házak számára vonzó adottságai. Ilyen körülmények között a bérházak, amelyek más helyeken nemcsak elfogadhatók, hanem egyenesen kívánatosak is, könnyen terhessé válnak." 12

Miközben e folyamat során kialakultak a kizárólag családiházas lakónegyedek kialakításának jogalapjai, nem jött létre ugyanennek a piaci feltétele. Ebben az időszakban a bérházak olcsóságuk és az általuk kínált kényelem révén igen népszerûvé váltak, építésük soha nem látott szintet ért el. A 20-as évek második felében a lakások $40 \%$-a többlakásos házban épült, sổt ez az arány a nagyvárosokban jóval magasabb volt.

Az elkövetkezó évtizedekben azonban a kormányzat határozott gazdasági és jogi lépéseket tett a családiházas lakónegyedek érdekében. A 30-as években (a recesszió idején) a lakásépító iparág felélesztésére a kormányzat új biztosítási formákat hozott létre a lakás célú megtakarítások támogatására, továbbá a lakások értékének $80 \%$-áig terjedôen pénzügyi fedezetet nyújtott a jelzálogkölcsönök biztosításához. Ennek eredményeképpen az alacsony kamatozású, hosszúlejáratú jelzálogkölcsönök széles körben hozzáférhetővé váltak. A II. világháborút követốen a családiházas kertvárosi övezet uralkodóvá vált az USA-ban. A szükséges infrastruktúrára viszont közpénzekbốl kellett jelentốs összegeket költeni. A jelzálog-biztosítási rendszer nagyrészt a családiházas övezetekhez kötổdött. ${ }^{13}$ Sôt, ezidốtájt az övezeti szabályozás a többlakásos építkezéseket már csak nagyon korlátozott mértékben engedte meg. ${ }^{14}$

Ezzel egyidốben a többlakásos formák (társasház, szövetkezet) a hitelkezelôk vonakodása miatt csak kevéssé fejlődtek ki. Továbbá az elmúlt két évtizedben a helyi hatóságok erổsen korlátozták a többlakásos bérházak társasházzá alakítását is.

A várostervezốk törekvéseinek közismert eredményeként az Egyesült Államok a családi házak országává alakult, a társadalom elfogadta az általuk kialakított ideológiát. Ma az Egyesült Államok háztartásainak kétharmada családi házban él, a városi népesség zöme kertvárosokban lakik. Az Egyesült Államok várostervezésének központi elemévé vált a családiházas övezetek létrehozása és megốrzése, illetve határozott elkülönítése a többlakásos övezetektôl, valamint a nem lakóterületi (intézményi, ipari) zónáktól.

\section{A költségvetési politika szerinti övezeti szabályozás (,,fiscal” zoning)}

Az Egyesült Államok területfelhasználási szabályozását érintô másik lényeges tényezôa a helyi költségvetési rendszerekhez és a szabályozás teljes decentralizálásához kötôdik. Bizonyos értelemben minden település önálló szigetet képez, amelynek területrendezési kérdésekben szinte kizárólagos hatalma van. Ezen túlmenôen jelentôs részben az önkormányzatok feladata, hogy maguk számára bevételeket teremtsenek. Ezek fố forrása a helyi vagyonadó. Az önkormányzatok feladata pedig, hogy a közösség számára biztosítsák az olyan alapvetõ szolgáltatásokat, mint az oktatás, közlekedés, közbiztonság.

Ebben az összefüggésben a területfelhasználás szabályozását elsốsorban nem a várostervezổi elképzelések, hanem sokkal inkább a gazdasági szempontok befolyásolják. A város minden projektrốl költség-haszon elemzést készít. Amikor egy projekt elfogadásáról dönt, összeveti a tervben szereplố potenciális ingatlanadókat és átruházási illetékeket, mint bevételeket, a terv megvalósulása esetén jelentkezỏ közszolgáltatási igények költségeivel. A városok azon versengenek egymással, hogy olyan koncessziókat ajánljanak, amelyek a kedvezố adóbevételeket biz- 
tosító fejlesztéseket vonzzák. Természetesen következik ebbôl, hogy a jelenlegi rendszer nem kedvez az alacsony jövedelmû társadalmi rétegeket kiszolgáló lakásépítésnek.

Bár elvileg a költség-haszon elemzések tudományos alapokon állnak, a valóságban ideológiai szinezetũek. Egy tervjavaslathoz kötốdố pénzügyi elemzés alapossága egyenes arányban áll annak népszerứtlenségével. A kialakult szocio-ökonomiai felfogás szerint a többlakásos házak építése a helyi költségvetés számára nagyobb terhet jelent, mint amennyi adóbevétel származik belôlük, ${ }^{15}$ tehát ez a konstrukció kevésbé kívánatos. A költség-haszon elemzés eredményének ilyen értékelését tovább erôsíti az ingatlantulajdonosok nem hivatalos és kimondatlan véleménye arról, hogyan befolyásolja a fejlesztési terv az ingatlanaik értékét.

\section{A várostervezés dilemmái napjainkban}

A várostervezôknek, a központi és helyi kormányzatoknak, a bíróságoknak manapság számos összeegyeztethetetlen értékszempontot kellene összhangba hozniuk a területfelhasználási tervek készítése során. Rendkívül bonyolult kontextusban kell ezekkel a dilemmákkal szembesülniük. A helyi területfelhasználás kérdéseiben kialakuló viták gyakran jóval élesebbek, mint az országos ügyekben indítottak, hiszen ezek hatása sokkal kézzelfoghatóbb és azonnali. A helyi területfelhasználási politika ugyanis alapvetốen meghatározza a lakásnak, az amerikai háztartások legjelentôsebb vagyontárgyának, az értékét.

A várostervezôk számára újabb nyomasztó terhet jelent, hogy úgy érzik, elôdeik elképzeléseinek kedvezôtlen hatásait is közömbösíteniük kell. A korábbi felfogás szerint olyannyira favorizált családi házas települési forma sivár külvárosokat hozott létre, amelyeknek hatalmasak az infrastrukturális és társadalmi költségei. A társadalmi rétegek életszínvonal-mércéjévé vált, hogy ki tudnak-e törni a belvárosból a kertvárosok felé.

A várostervezés a következố - egymással ellentétes - tényezók figyelembe vételén alapul a demokratikus berendezkedésũ piacgazdaságokban:

1. demokratikus ellenörzés

2. az ,érdekérvényesítés" és a ,jogszerû́ség",

3. a tulajdonjog védelme

4. környezetvédelem

5. rendezettség

6. a legszegényebb csoportok jogainak védelme

A nyugati társadalmak területfelhasználási tervezésének tapasztalatai nem feltétlenủl pozitívak. Rendkívül nehéz a területfelhasználási szabályozás és az építési szabályzatok olyan rendszerét létrehozni, amely valóban jól mûködik. ${ }^{16}$

\section{A demokratikus ellenốrzés biztosítása}

A helyi területfelhasználási terveknek alapvetó értékként kell kezelniük a demokráciát. A legtöbb városban a jelentốsebb projektek engedélyezési dỏntéseit az ún. , ,építési övezet bizottság" (zoning board) hozza meg, amelyet a városi tanács tagjai neveznek ki. Az ilyen bizottságoknak minden esetben nyilvános meghallgatásokat kell tartaniuk. 
A demokratikus elvekkel összhangban a helyi területfelhasználási szabályozás terén a politikai alapon választott önkormányzati szervek széles döntési jogkörrel rendelkeznek abban, hogy támogatnak vagy elvetnek egy-egy adott projektet. Objektív, adminisztratív módon alkalmazható kritériumok meghatározása helyett a jogszabály a helyi testületek feladatává teszi, hogy megítéljék a projekt jóléti és környezeti hatásait anélkül, hogy meghatározná, milyen mértékben, milyen súllyal vegyék figyelembe az ellentmondó szempontokat. Mindez a valóságban ,,zöld utat", szabad kezet ad a helyi testületeknek a területszabályozási döntésekben.

Az ilyen szabályozás tipikus példája a következố:

Egy adott engedély kiadása kapcsán a döntéshozók a következőket fogják figyelembe venni: - az adott terület alkalmas-e a javasolt funkcióra;

- a javasolt funkció becsülhetô hatása a forgalomra, a tervezett úthálózat kapacitására és más közszolgáltatásokra;

- a javasolt funkció becsülhetố gazdasági hatása a környezổ területekre;

- a javasolt funkció becsülhető hatása a település lakóinak általános jólétére;

- a terv illeszkedése a csatlakozó területekhez és a környezethez. ${ }^{17}$

A demokratikus ellenốrzés alapelve minden olyan esetben konfliktushoz vezet, amikor a várostervezés olyan értékeket helyez elôtérbe, amelyeket a nagy többség nem képvisel. A vagyonhoz való jog szerint kártérítés ellenében lehetséges a közcélú kisajátítás, azonban a többség nem fogja támogatni ezt az elvet, ha az egyébként népszerü városi projekt ilyen módon költségessé és irreálissá válik. Az alacsony jövedelmú csoportok jogainak védelme érdekében elengedhetetlen, hogy olyan lakóházak is épüljenek, amelyek e csoportok számára is elérhetóek. Ezt az elvet a várostervezók és a szociális aktivisták széles körben támogatják, de a középpolgár élénken tiltakozna, ha ilyen jellegú építkezés kezdődne lakóhelye közelében.

\section{Az érdekérvényesités és a jogszerüség biztositása}

A nyugati társadalmak alapelve, hogy egyes személyek nem állhatnak a jog felett és hogy a döntéshozó folyamatokban mindenki számára biztosítani kell a lehetôséget, hogy álláspontját kifejthesse. Az Egyesült Államokban a területfelhasználás szabályozásába olyan eljárási elemek vannak beépítve, amelyek a folyamat tisztaságát hivatottak biztosítani. A szabályozás változását célzó javaslatokról, a projektekről a nagyközönséget és az érintett szomszédokat részletes elốrások szerint tájékoztatni kell. A szabályok általában újságfelhívások közzétételét, hirdetmények kitűzését követelik meg, a projekt vagy a jogszabály-változás által érintett körzetekben a tulajdonosokat levélben kell értesíteni.

Minden elốterjesztést, amelyet az önkormányzat szakelốadója a politikai testület elé visz, nyilvános iratként kell kezelni, s a felterjesztéssel egyidóben hozzáférhetôvé kell tenni a nagyközönség számára is. A dokumentumokat a tervezett nyilvános meghallgatások előtt meghatározott idôvel publikálni kell.

Az érdekérvényesítés követelményei viszonylag könnyen teljesíthetôk, a jogszerúség biztosítása jóval körülményesebb. A területfelhasználás feletti demokratikus ellenőrzés elve közvetlen összeütközésbe kerülhet a jogszerû́ség elveivel, hiszen a helyi politikai testületek széles döntési szabadsággal rendelkeznek a területfelhasználás felett (minthogy nem tudnak szigorú, és objektív kritériumokat alkalmazni). A gyakorlatban ez a döntési szabadság minden jogi 
alátámasztás nélkül alkalmazható politikai döntési szinteken. A kormányzó szerv lényegében tehắt törvényhozó szerepet játszik, ahelyett hogy tényfeltáró testületként az egyes esetekben az érvényes jogszabályok alkalmazására lenne kényszerítve.

Az ilyen szerepzavarok elkerülésére az állami törvényhozás és a bíróságok olyan követelményeket dolgoztak ki, amely szerint a kormányzati döntéseket megfelelổ tényfeltáró munkának kell megelốznie, ami jogalapot biztosít az egyes döntésekhez. Egy terv engedélyezése során például szükség lehet a projekt forgalmi és zajhatásainak vizsgálatára, a lakásellátási (piaci) következmények ellemzésére.

E követelmények ugyan elméletileg törvényességi irányelveket építenek be a döntéshozó folyamatba, a gyakorlatban azonban hatásuk erôsen korlátozott. A jogi kritériumok a gyakorlatban olyan komplexek és szubjektívek, hogy a szakértôk és a laikusok következtetései alapvetôen különbözốek lehetnek. A valóságban az történik, hogy a döntéshozó testület meghozza döntését, majd megkeresi a szabályok és a tények olyan kombinációját, amivel ezt a döntést alátámaszthatja. A tervezéssel foglalkozó munkatársak szerepe inkább az, hogy a megkívánt eredmény indokait teremtsék elố, szemmint hogy valódi elemzést végezzenek.

Amennyiben a városi tanács például egy tervet építészeti kialakítása vagy környezetrendezési javaslatai miatt akar visszautasítani, de erre nincs törvényes lehetósége, más indokokat fog keresni az elutasításhoz. Kijelenti például, hogy a projekt túl nagy forgalmat és zajt fog okozni, és arra utasítja munkatársait, hogy olyan tényeket keressenek, amelyek ezt igazolják.

A törvényességi felülvizsgálat eszköze további biztosítékot ígér a jogszerüségre. A bíróságok azonban nehéz helyzetben vannak, hiszen ha a szubjektív elemeket is tartalmazó köztestületi dơntéseket felülvizsgálják, ismételten csak jogszabályalkotóként múködnek. ${ }^{18} \mathrm{Az}$ a lehetőség marad tehát csak számukra, hogy a felülvizsgálatot arra szứkítve végezzék el, hogy a döntést alátámasztja-e valamilyen ,,megalapozott” bizonyíték, vagy sem. Ez az utóbbi lehetôség azonban szinte egyenlő a felülvizsgálat hiányával, hiszen szinte bármely döntés alátámasztására kơnnyedén lehet ,,megalapozott bizonyítékokat” találni.

A gyakor latban tehát a bíróságok gyorsan érvénytelenítik azokat a döntéseket, amelyek nem követik a megkívánt eljárási rendet, de eközben az érdemi döntések visszautasítására ritkán kerül sor. A területfelhasználási döntések ellenzổinek ki kell mutatniuk, hogy a döntéshozó hol tévedt el a jogszabályok labirintusában. Tényleges elutasítás azonban csak akkor születik, amikor a választott testület felületességból vagy éppen túlzott magabiztosságból nem veszi a fáradtságot, hogy elkészítse a megkívánt , tény feltáró vizsgálatokat”, vagy nem eléggé kifinomult ahhoz, hogy elrejtse a döntés jogi kereteken kívüli szempontjait.

\section{Az ingatlan-tulajdonosok jogainak védelme}

A piacgazdaságon alapuló társadalmak egyik alapelve az, hogy a tulajdonost kárpótolni kell, ha az állam vagy a helyi hatóság elveszi a vagyonát. Ezt az Egyesült Államok alkotmánya tételesen is kimondja. Miközben ez az elv világszerte elfogadott, alapvetó viták és véleményklilönbségek vannak abban a kérdésben, hogy mikor és hogyan alkalmazható. A tulajdonosok jogainak védelme alapvetõen ellentétben áll azzal a szándékkal, hogy az önkormányzatok közérdekbốl szabályozzák a területfelhasználást, és kerüljék el a határtalan mértékú kompenzáclót. 
A XIX. században a kártérítés elvét úgy értelmezték, hogy azt csak a birtok tényleges fizikai csorbítása és a kormányzatok által végrehajtott jogszerũ kisajátítások alkalmával kell érvényesíteni. Késôbb olyan helyzetekre is alkalmazták, amikor a kormányzat tevékenysége közvetett hatása révén okozott vagyoni kárt. ${ }^{19}$ A legutóbbi idôben a kártérítési igény már a kormányzatok , szabályozási” tevékenységére is kiterjedhet.

Az Egyesült Államok Legfelsôbb Bíróságának jelenlegi állásfoglalásai alapján a fizikai igénybevétel olyan nyilvánvaló kisajátítás (taking), amely annak valódi nagyságától függetlenül minden képpen kártérítést tesz szükségessé. A szabályozási jellegủ korlátozások kapcsán a bíróságoknak minden esetet a körülmények összességének figyelembevételével kell megítélnie. A Legfelsốbb Bíróság több alkalommal kifejtette, hogy nem lehet szilárd alapelveket felállítani arról, mit is jelent ezekben az esetekben a vagyoni jog korlátozása. Az egyetlen általános szabály - mely azonban bizonytalan -, hogy a tulajdonos akkor léphet fel kártéritési igénnyel, ha a szabályozás miatt ingatlanának semmilyen gazdaságilag reális használata nem képzelhetổ el .

Ezt az elvet általában arra használják, hogy a legszélsốségesebb esetek kivételével ne legyen szükség kárpótlásra. A zónahatárok megváltoztatása kapcsán valamely ingatlan értékének akár 90\%-át is elvesztheti anélkül, hogy szükségképpen kártérítés alapját képezô ,,igénybevételnek" minôsiülne.

Ha csak lehetséges, a Bíróság okot talál arra, hogy ne hozzon döntést. Az elutasítás általános oka, hogy a felperes nem használt ki minden jogorvoslati fórumot. Ez azt jelenti, hogy ha csak egyetlen fórumot is kihagyott az érdekelt, azt pótolnia kell annak érdekében, hogy a bíróság pontosan megtudja, a helyi hatóság milyen fejlesztéseket enged meg. A fellebviteli eljárások igen magas költségeit, és a jogi folyamatok hosszúságát (s ezek akár több évig is tarthatnak) figyelembe véve a jogorvoslati fórumok kihasználásának elve az érintettek kifárasztását szolgálja, és lehetetlenné teszi, hogy panaszaikra reális idôn belül érdemi választ kapjanak.

Amikor a bíróság egy adott eset kapcsán döntést hoz, határoz alapvetố kérdésekben, gondosan ügyel arra, hogy döntésének hatályát egy szúk területre korlátozza, s így lehetetlen felmérni, hogy egy következô, nagyjából hasonló ügyben milyen dỏntést hozna.

A bíróság magatartását könnyư kritizálni, de ezt annak fényében kell tenni, hogy szinte lehetetlen feladat meghatározni a pontos irányelveket arról, hogy mi minôsíthetố a vagyoni jogok korlátozásának. Mindezen realitások ismeretében a helyi hatóságok olyan esetekben is nagy ügyességgel hárítják el a kártérítési igényeket, amikor olyan korlátokat állítanak fel, melyek nyilvánvalóan akadályozzák a területek fejlesztését.

\section{Rendezettség}

A várostervezés eredetileg azért fejlốdött ki, hogy az iparosodás és a gyors városfejlốdés következtében kialakuló városi rendezetlenséget és túlzsúfoltságot megelốzze. ${ }^{20} \mathrm{~A}$ külsố megfigyelô szemében a Rend mindig az, ami a korszellem és a hatalom felfogásának megfelel. A XIX. sz.-ban a városi rend a szabályos rácshálót jelentette, késóbb ezt az elrendezést monotonnak találták. E században a rend az ipari, kereskedelmi, többlakásos és családiházas területek szétválasztását jelentette. A mai felfogás szerint viszont ez a gondolat okozta a nemkívánatos szuburbanizációt, a hatalmas infrastruktúrális költségeket, a gépjármû́vek szennyezését, és a társadalmi elidegenedést. 
Környezeti szempontok és a „NIMBY"21 (,,ne az én portám mellett”) mozgalom

A legutóbbi évtizedekben a környezet pusztulása központi politikai és társadalmi kérdéssé vålt. Az Egyesült Államok területfejlesztési törvényei általában részletesen elổíják a projektek kơrnyezeti hatástanulmányainak követelményeit. A nyilvános meghallgatások elôtt a tervezési hatóságoknak olyan anyagokat kell készíteniük, amelyek a környezeti hatások minden típusát elemzik, alternatívákat állítanak a javasolt projekt mellé, bemutatják az ártalmak csökkentésének eszközeit. A környezeti hatásokról külön meghallgatásokat kell tartani.

A várostervezốk és a környezetvédelmi szakemberek a javasolt projektek megítélésekor sokfẩle társadalmi és környezeti szempontot vehetnek figyelembe. A nagyközönség képviselổi ugyanakkor legtöbbször a közvetlen környék iskoláival, forgalmával, zajszintjével és ingatlanéitékének változásával kapcsolatban szólalnak fel.

Az Egyesült Államokban az említett értékek mentén indult meg az igen erôs NIMBY mozgalom, elổsorban azokon a helyeken, ahol a fejlesztés nyomása a legerôsebb, a lakáshiány a legsúlyosabb. A környék lakói sok esetben a fejlesztéseknek semmilyen hasznát nem látják, a potenciális haszonélvezôk viszont külsố emberek, akik nem vesznek részt a helyi döntési folyamatokban.

Míg korábban a fejlesztôk tudtak olyan tervekkel jelentkezni, amelyek beilleszkedtek az érvényes elốírások rendszerébe, mostanában a terveket érintố szempontok végtelen sorának kell megfelelniük, ami az önkormányzati testületnek lehetôséget ad arra, hogy úgyszólván bármilyen javaslatot visszautasítson.

\section{A legszegényebb csoportok jogainak biztositása}

A várostervezốk célja az is, hogy minden társadalmi csoport számára elfogadható és elérhetổ lakást biztosítsanak. A szegény országokban a legszegényebbek általában a külvárosokban építik fel házaikat, s bár a középosztály mércéje szerint ezek a lakások nem megfelelôek, létezésük mégis elfogadott. Az iparosodott nyugati országokban az ilyen piaci szempontokat követố fejlesztések nem megengedettek, mert a közjólét eszméivel ellentétesnek minôsülnek. ${ }^{22}$

Az Egyesült Államokban sokhelyütt a lakosság és a szakértôk az egészségvédelem, a biztonság, a környezetvédelem, a rendezett fejlesztések vagy a pénzügyi megfontolások olyan érveivel fegyverkeztek fel, amelyekkel gyakorlatilag minden, az alacsony jövedelmû́ rétegek számára kidolgozott projektet meg tudnak akadályozni. Az ilyen szabályozások például a minimális telekméretet negyed vagy fél hektárban írják elô, a többlakásos lakóházakban megkövetelik a lakásonként egy vagy két parkolóhelyet, miközben a szegények kizárásának szalonképtelen szándéka természetesen sehol nem jelenik meg. Az ilyen kivételezố politika eredményeképpen a szegény rétegek kiszorulnak a kevezôtlenebb területekre, ugyanakkor teljesíteniük kell a középosztályra jellemzố egészségügyi vagy biztonsági követelményeket is, amire anyagilag képtelenek.

Az elmúlt évtizedekben több állam jogszabályalkotói és bíróságai rákényszerítették a helyhatóságokat, hogy tisztességes arányban elfogadják területükön az alacsony jövedelmû́eknek épített házakat is. A rendkívül határozott New Jersey Legfelsôbb Bíróság elôirta, hogy a településeken megfelelổ arányban kell biztosítani elérhetố árú lakásokat is, ${ }^{23}$ de a ,,megfelelố arány" megállapítását hosszas és költséges eseti vitákra és pereskedésekre bízta. Késốbb, mikor már 
látható volt az eredeti szándékok eredménytelensége, a bíróság speciális szabályokat léptetett életbe az önkormányzatok ellen, ${ }^{24}$ ezeket azonban erôsen gyengítették az állami elöírások. A szegény rétegek kizárását megakadályozó jogszabályok többnyire más USA tagállamokban is olyan általánosak, hogy a helyi hatóságok kivételezố ereje lényegében messze túlnổ a tagállamok és a bíróságok szándékain.

\section{Szembesülni a dilemmákkal}

A településtervezési rendszer átalakulásával párhuzamosan lényegesen megváltozik a várostervezố szerepe Magyarországon is. Az önkormányzati testületek jóval nagyobb befolyással rendelkeznek a tervezési folyamatban, mint a múltban. Ốk választhatják meg a tervezốt, s ốk dönthetnek arról is, hogy elfogadják-e a tervet vagy sem. Jelenleg arról folyik a vita, hogy szükség van-e egyáltalán a részletes rendezési tervekre a jelenlegi formájukban (ezek inkább projektek, beruházások elổtervei), s hogy annak tervezôjét a befektetố, vagy a város választhassa-e meg. A szerzố a várostervezókkel készített interjúi során gyakran érzékelte a befektetôk által készített és elốterjesztett rendezési tervekkel kapcsolatos aggodalmakat. A szakemberek attól félnek, hogy a befektetốk rossz irányba befolyásolják és zavarják a városi testületek tagjainak ítéleteit.

Az iparosodott országokban a várostervezók szakértelme egyaránt szolgálhat jó és rossz célokat. Amerikában ốk nyújtottak segítséget az elôvárosi családiház-óceánok létrehozásának jogi indoklásához, Kelet- és Nyugat-Európában a sivár lakótelepek kialakításához.

Most, amikor a várostervezốk úgy érzik, hogy nekik kell megvédeniük a közérdeket a választott politikusok szeszélyeitôl és tudatlanságától, a politikusok már gyakran alig tartanak igényt a tervezốk szakértelmére, érveire és céljaira. A tervezési folyamat ugyanakkor a bírálatok kereszttüzében áll, mert nem képes összeegyeztetni az összeegyeztethetetlen célokat, mert nem tud felülkerekedni az áthidalhatatlan akadályokon.

A törvények ma lehetổvé teszik a jó tervezést, de csodareceptek nem léteznek. A legtöbb, amit tehetünk, hogy egy jó döntési eljárást alakítunk ki, ami képes arra, hogy a különféle érdekek között elfogadható egyensúlyt hozzon létre. Ezzel kapcsolatban lehet néhány javaslatot tenni. Mindenekelốtt törekedni kell arra, hogy olyan eljárási folyamatok jöjjenek létre, amelyek korlátozzák az aránytalanul nagy hatalom koncentrálódását. Ebben a folyamatban fontos lépés, hogy hozzáférhetőek legyenek az információk, közelítóleg pontosak a határidôk, hogy további eljárási lépések beiktatásával ne lehessen gyakorlatilag a végtelenségig elhúzni a döntési folyamatot.

A , jó tervezés" lényeges eleme, amit nem lehet jogszabályban meghatározni, hogy figyelemmel kell lenni mások szempontjaira, véleményére, és arra is, hogy ezeket kinyilváníthassák. Ha a választott tisztségviselốk és/vagy a szakemberek úgy érzik, hogy elképzeléseik , Istentôl eredőek", akkor céljaik szentesíteni fogják eszközeiket, s a várostervezés tekintélye megszúnik. A várostervezốk becsapják önmagukat és a közösséget, amelyet szolgálniuk kellene, ha úgy érzik, hogy ốk tévedhetetlen tudósok, s nem csupán egyszerü emberek, akik a saját nézeteiknek leginkább megfelelổ elổíásokat alkalmazzák döntéseik során.

Mind a választott képviselôknek, mint a várostervezôknek arra kell törekedniük, hogy lehetốvé tegyék és ösztönözzék a társadalom lehetổ legszélesebb közremứködését, hogy így ellensúlyozzák saját korlátaikat és tévedéseiket. 
Kenneth K. Baar : A területrendezés dilemmái a demokratikus piacgazdaságokban

(Pilemmas of land use planning in a democracy with a market economy)

Tér és Társadalom 6. évf. 1992/1-2. 89-99. p.

\section{Jegyzetek}

${ }^{1}$ Környezetvédelmi és Területfejlesztési Minisztérium, Országos Építésügyi Hivatal: Az épített környezet alakításáról, fejlesztéséról és védelmérốl szóló törvény szakmai koncepciója (Budapest, 1992. április).

21981 és 1986 között a lakásépítés nagyságát 69-76 000 évente átadott lakás jellemezte. 1990-ben azonban már csak 43771 lakás készültt. 1991-ben kb. 32000 lakást építettek.

${ }^{3}$ Évi $30 \%$ körüli.

- Zavaró hatások (nuisances) azok, amik ténylegesen lehetetlenné teszik a szomszédos ingatlan rendeltetésszerú használatát: nagy mértékú füstszennyezés, por-lerakódás, elviselhetetlenül magas zaj, bứz stb.

${ }^{5}$ A tulajdonosok között, közjegy zổ elốtt kötött megállapodások, amelyek meghatározzák az ingatlanok használatát (pl. kizárólag családiház építhetô). E szerzôdések a földterülethez kötởdnek, és kötelezố érvényứek mind a jelenlegi, mind a jövớbeni tulajdonosokra nézve.

- Veiller (1914) Protecting Residential Districts, 10, American City 525, June.

' Ebben az idớben a lakásokban fürdôszzoba és saját WC is volt.

${ }^{8}$ Ford, James, (1913) Some Fundamentals of Housing Reform, 8, American City 476 (1913).

9 A bérház-ellenes mozgalomról lásd Baar, (1992) The Notinal Movement to Halt the Spread of Multifamily Housing, 1890-1926, American Planning Association Journal 58 (1) 39-48. (1992).

${ }^{10}$ Euclid v. Ambler, (1926) 272 U. S. 365.

"Lochner v. New York, (1905) 198 U. S. 45.

${ }^{12}$ Supra note 10. 272 U. S. at 394-5.

${ }^{13}$ A kölcsön egyik feltételéül szabták, hogy a ház családiházas övezetben épüljön.

14 Általában a lakóterület kevesebb mint $1 \%$-át minôsítették többlakásos ház építésre alkalmasnak. Ld. pl. Report of the National Commission on Urban Problems, Building the American City (U. S. House of Representatives Document No. 91-34, 91st Congress, 1st Sess., 1968, p. 215 and Report of the President's Committee on Urban Housing (Technical Studies, Vol. II, 1968).

15 A közfelfogás szerint az úthálózat - a gyéren lakott területeken igen magas - költsége , ,közkiadás”, míg a tömegközlekedés költségei - melyek a többlakásos területeken jelentkeznek elsősorban - ,állami támogatás"nak minốsülnek.

${ }^{16}$ Néhány nagytekintélyư várostervezỗ úgy látja, hogy a várostervezés több kárt okoz, mint hasznot.

17 Fremont, Californja Municipal Code Sec. 8-22552.

18 Amikor a bíróságok a század elsó negyedében jogszabályalkotó szerepet játszottak, az eredmény kétségbeejtő̉nek bizonyult. Az al apvetô szociális törvények (mint pl. a minimálbér törvény)érvény telenítése a bíróságok azon véleményén alapult, hogy azoknak nincs racionális alapja. A gazdasági visszaesés idején a Legfelsốbb Bíróság a szociális törvények megítélését már arra szükítette le, hogy van-e azoknak egyáltalán alapjuk.

19 Pl. jelentốs reptéri zaj.

${ }^{20}$ Az Egyesült Államok várostervezésének történetérốl lásd Scott, Mel, American City planning (1969, Berkeley, Univ. of California Press).

" A ,,NIMBY" új mứszó, melyet a várostervezók a növekedésellenes színdróma jelzésére használnak.

${ }^{22}$ Az Egyesült Államokban az elérhetô árú lakások problémájáról ld. ,,Not in My Backayard”' Removing Barriers Affordable Housing (Report to President Bush and Secretary Kemp by the Advisory Commission on Regulatory Barriers to Affordable Housing, 1991).

${ }^{23}$ South Burlington County N.A.A.C.P. v Township of Mt. Laurel, 67 N. J. ISI, 336 A.2d 713 (1975).

24 Id., 92 N. J. 158, 456 A. 2d. 390 (1983). 
Tér és Társadalom 6. évf. 1992/1-2.
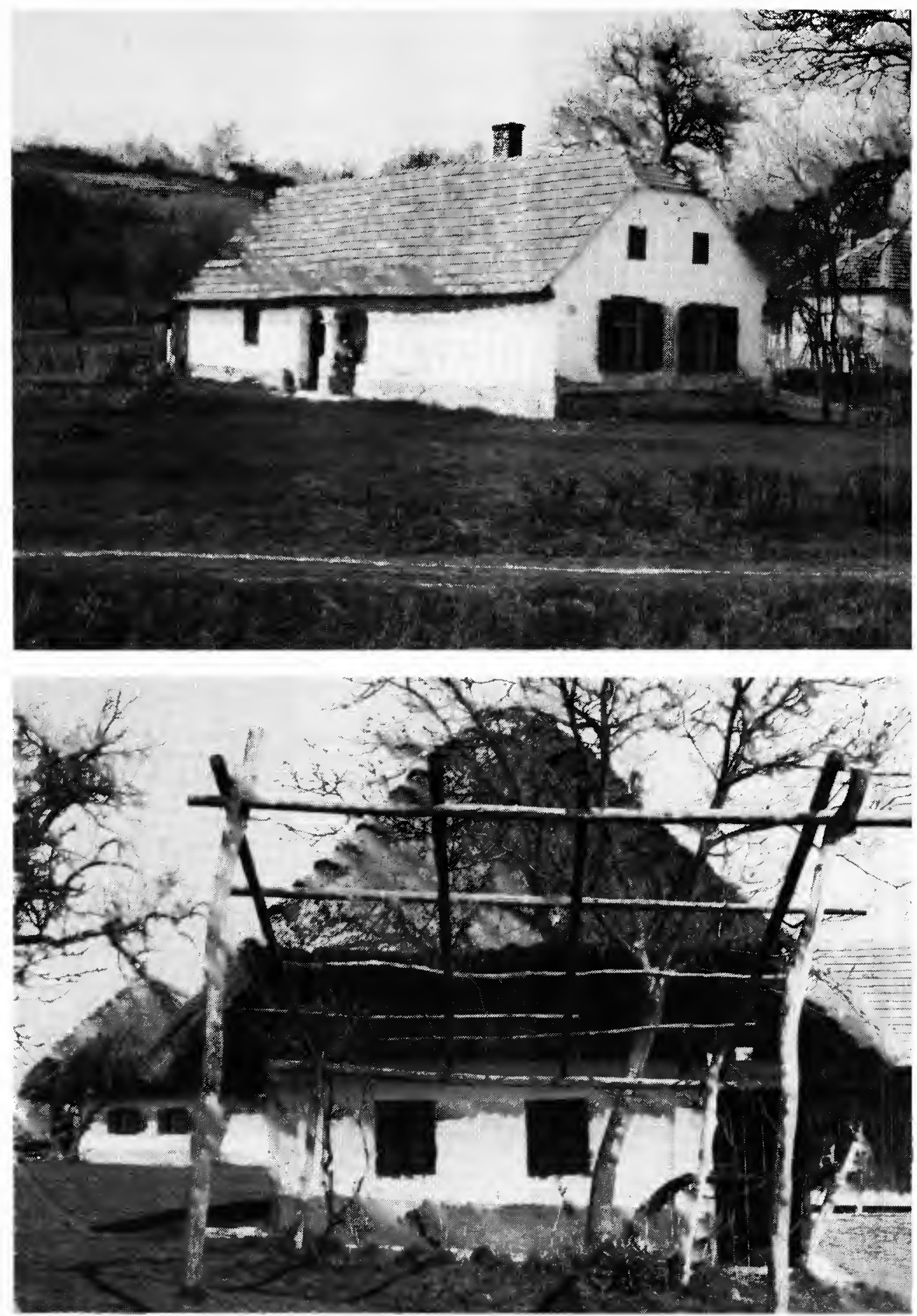